\title{
A Case of Suspected Mediastinal Germinoma: Enzyme Histochemical and Ultrastructural Findings
}

\author{
Osamu KoIde ${ }^{1}$, Shigetoshi Iwai ${ }^{1}$, Hiroshi Yoshimatsu' ${ }^{2}$, Masao SumiYama ${ }^{3}$ \\ and Koichi MATSUDA ${ }^{3}$ \\ ${ }^{1}$ Department of Pathology and Surgical Pathology, School of Medicine, University of Occupational \\ and Environmental Health, Japan. Kitakyushu 807, Japan \\ ${ }^{2}$ Depariment of Thoracic Cardiovascular Surgery, School of Medicine, University of Occupational \\ and Environmental Health, Japan. Kitakyushu 807, Japan \\ ${ }^{3}$ Department of Surgery, Hamamatsu Red Cross Hospital. Hamamatsu 430, Japan
}

Abstract: Mediastinal germinoma is an uncommon tumor. In the present paper, enzyme histochemical and ultrastructural findings of a mediastinal germinoma of a 35-year-old male is reported by means of a surgical specimen of an exploratory excision. The enzyme histochemical study on mediastinal germinoma has never been found in any literatures. The tumor cells were strongly positive for alkaline phosphatase staining, the isoenzyme of which was assumed to belong to the kidney type. Some of the tumor cells were positive for acid phosphatase and $\beta$-glucuronidase stainings, and the majority of the tumor cells were positive for $\alpha$-naphtyl acetate esterase stainings, but negative for $\alpha$-naphtyl butyrate esterase and adenosine triphosphatase. Ultrastructurally, the tumor cells, ovoid in shape and occasionally with a cell process, possessed a nucleus containing nucleoli with distinct nucleolonema, scanty organelles and a great number of glycogen granules. Annulate lammelae and stacks of rough-surfaced endoplasmic reticulum were found in some of the tumor cells. No junctional apparatus was observerd. There findings were similar to the ones of germinomas originating in other sites, and excluding the thymoma.

Key words: mediastinal germinoma, enzyme histochemistry, alkaline phosphatase isoenzyme, ultrastructure.

(Received 17 February 1981)

Malignant tumors which have morphological features similar to those of germ cell tumors of the testis or ovary are sometimes found in the anterior mediastinum as well as in the cranial cavity, retroperitoneum and sacrococcygeal region. However, the incidence of the germ cell tumors was reported to be 2 to $6 \%$ of the anterior mediastinal tumors (Cox, 1975) and Yoshimatsu et al. (1980) treated only 3 patients with germinoma (seminomatous tumor) in 69 patients with thymic tumor. Enzyme histochemical or ultrastructural studies on germinoma arising in the anterior mediastinum are very rare, as the incidence of the tumor is low and it is rarely diagnosed before an operation. This paper is a report of the enzyme histochemical and ultrastructural study on a surgical specimen of mediastinal germinoma of a 35-year-old male. 


\section{Case Report}

A 35-year-old male, truckdriver, complaining of a cough for 3 months was found to have an abnormal shadow of the mediastinum when X-rayed during his annual physical checkup (Fig. 1). Since the tumor was invading the upper lobe of the right lung, pulmonary hilus and pericardium, and pulmonary blood vessels were surrounded by the tumor, on December 24, 1979, an exploratory excision of the mediastinal tumor was performed. The patient was given a series of Liniac radiation therapies consisting of 5,000 rad, resulting in perfect health for a year.

\section{Materials and Methods}

A neoplastic tissue cut in a slice approximately $5 \mathrm{~mm}$ thick was divided into two portions. One portion of the tissue was fixed in a combination of $4 \%$ commercial formaldehyde and 1\% glutaraldehyde (4F1G) (McDowell \& Trump, 1976) and the other in $10 \%$ formol-calcium ( $\mathrm{pH} \mathrm{7.1)}$, both stored at $4^{\circ} \mathrm{C}$. The former was used for histologic and electron microscopic observations and the latter for enzyme histochemistry.

The superficial portion of the tissue fixed in $4 \mathrm{~F} 1 \mathrm{G}$ was partly cut into about $1 \mathrm{~mm}^{3}$ fragments, and postfixed in cold 1\% osmium tetroxide. The specimens were then dehydrated through graded ethanols, rinsed with acetone, and embedded in Epon 812. Ultrathin sections were doubly stained with uranyl acetate and lead nitrate, and observed with a JEOL $100 \mathrm{C}$ electron microscope. The other portion of the tissue fixed in $4 \mathrm{~F} 1 \mathrm{G}$ was

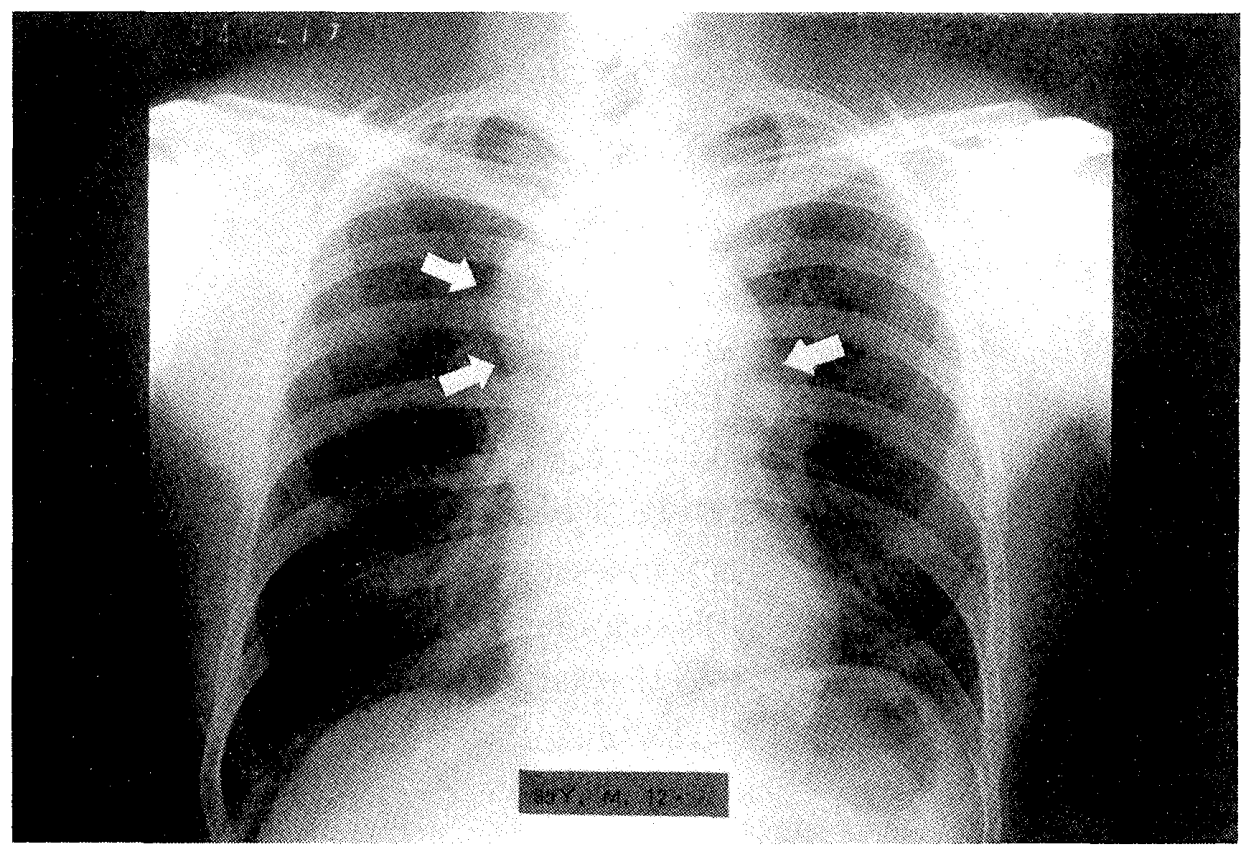

Fig. 1. Chest X-ray film showing the enlargement of the upper mediastinal shadow. 
Table 1. Staining methods used in enzyme histochemistry

\begin{tabular}{|c|c|c|c|c|c|}
\hline Enzyme & Substrate & $\begin{array}{l}\text { Incubati } \\
\text { Time (min) }\end{array}$ & $\begin{array}{l}\text { on } \\
\text { Temp. }\end{array}$ & Inhibitor & $\begin{array}{l}\text { Method } \\
\text { ref. }\end{array}$ \\
\hline \multirow[t]{7}{*}{ AlPase } & Naphthol AS-BI phosphate & 15 & room & & 1) \\
\hline & & 15 & room & $\mathrm{L}-\mathrm{Ph}$ & 2) \\
\hline & & 15 & room & $\mathrm{D}-\mathrm{Ph}$ & 2) \\
\hline & & 15 & room & $\mathrm{L}-\mathrm{H}$ & 2) \\
\hline & & 15 & room & $\mathrm{L}-\mathrm{L}$ & 2) \\
\hline & & 20 & $47^{\circ} \mathrm{C}$ & Heat & 3) \\
\hline & & 20 & $65^{\circ} \mathrm{C}$ & Heat & 3) \\
\hline AcPase & Naphthol AS-BI phosphate & 30 & room & & 4) \\
\hline$\beta$-Gase & Naphthol AS-BI- $\beta$-D-glucuronide & 30 & $37^{\circ} \mathrm{C}$ & & 5) \\
\hline ATPase & Adenosine triphosphate & 30 & room & & 6) \\
\hline$\alpha \cdot N$. acet. est. & $\alpha$-Naphthyl acetate & 30 & room & & 7) \\
\hline$\alpha$-N. but. est. & $\alpha$-Naphthyl butyrate & 30 & room & & 8) \\
\hline
\end{tabular}

*Abbreviation: AlPase (alkaline phosphatase), AcPase (acid phosphatase), $\beta$-Gase ( $\beta$-glucuronidase), $\quad \alpha$-N. acet. est. ( $\alpha$-naphthyl acetate esterase), $\alpha$-N. but. est. ( $\alpha$-naphthyl butyrate esterase), L-Ph (L-phenylalanine), D-Ph (D-phenylalanine), L-H(L-homoarginine), L-L (L-leucine)

**Method references: 1) Watanabe \& Fishman (1964), 2) Rufo \& Fishman (1972), 3) Posen et al. (1965), 4) Barka \& Anderson (1962), 5) Hayashi et al. (1964), 6) Wachstein \& Meisel (1957), 7) Yam et al. (1971), 8) Li et al. (1972)

embedded in paraplast, and sections were stained with hematoxylin and eosin, and a periodic acid-Schiff (PAS) reaction with or without diastase digestion test was performed.

The tissue fixed in 10\% formol-calcium for 18 hours was then kept in cold gum sucrose for 48 hours, and sectioned by a cryostat at $5 \mu \mathrm{m}$ thick. The sections were processed for several enzyme histochemical stainings: alkaline phosphatase (AlPase) with or without varying inhibition tests, acid phosphatase (AcPase), $\beta$-glucuronidase ( $\beta$-Gase), adenosine triphosphatase (ATPase), $\Leftarrow$-naphthyl acetate esterase $(\kappa-\mathrm{N}$. acet. est.), and $\Leftarrow$-naphthyl butyrate esterase $(c-\mathrm{N}$. but. est. ). For several amino acid inhibition tests of AlPase the sections were incubated for $15 \mathrm{~min}$ at room temperature in a medium containing naphthol AS-BI phosphate and $0.05 \mathrm{M}$ respective inhibitors, and for heat stability tests the sections were exposed for 20 min at $47^{\circ} \mathrm{C}$ and $65^{\circ} \mathrm{C}$ in a $0.005 \mathrm{M} \mathrm{MgCl}_{2}$ solution. Technical details are shown in Table 1.

\section{Observations}

\section{Histologic findings}

The tumor tissue revealed indefinite alveolar structures composed of large neoplastic cells surrounded by delicate stroma occasionally with epitheloid cell clusters and lobulated by broad septa of dense collagen fibers. Large neoplastic cells having a definite cell border, polyhedral shape and a vast amount of clear cytoplasm contained a large nucleus 
ovoid in shape with a few eosinophilic nucleoli and finely reticular chromatin. The clear cytoplasm was positive for PAS reaction digestable with diastase. Some portions of delicate stroma as well as broad septa were infiltrated with a small number of lymphoid cells (Figs. 2 and 3 ).

\section{Enzyme histochemical findings}

Sections exhibiting any enzyme activity in or on the tumor cells were designated as enzyme positive. The enzyme positivity was classified into 3 grades ranging from + to $3+$. The tumor cells had a strong positive reaction of AlPase (Fig. 4). Examining the AlPase isoenzyme, the AlPase activity of the tumor cell was completely inhibited by heating at $65^{\circ} \mathrm{C}$, slightly inhibited when treated with L-phenylalanine as well as L-homoarginine, and not inhibited when treated with $\mathrm{D}$-phenylalanine as well as L-leucine and heated at $47^{\circ} \mathrm{C}$. As compared with the human placenta, human liver and mouse kidney, the AlPase activity of the tumor cells showed sensitivity to the inhibitors similar to that of the kidney AlPase.

Some of the tumor cells showed granular activity of AcPase (Fig. 5) and dotted activity of $\beta$-Gase in their cytoplasm. Moderate to strong activity of AcPase and $\beta$-Gase was found in stromal macrophages. Tumor cells were negative for ATPase staining. Several spotted $c-\mathrm{N}$. acet. est. activity was found in most of the tumor cells (Fig. 6), however,

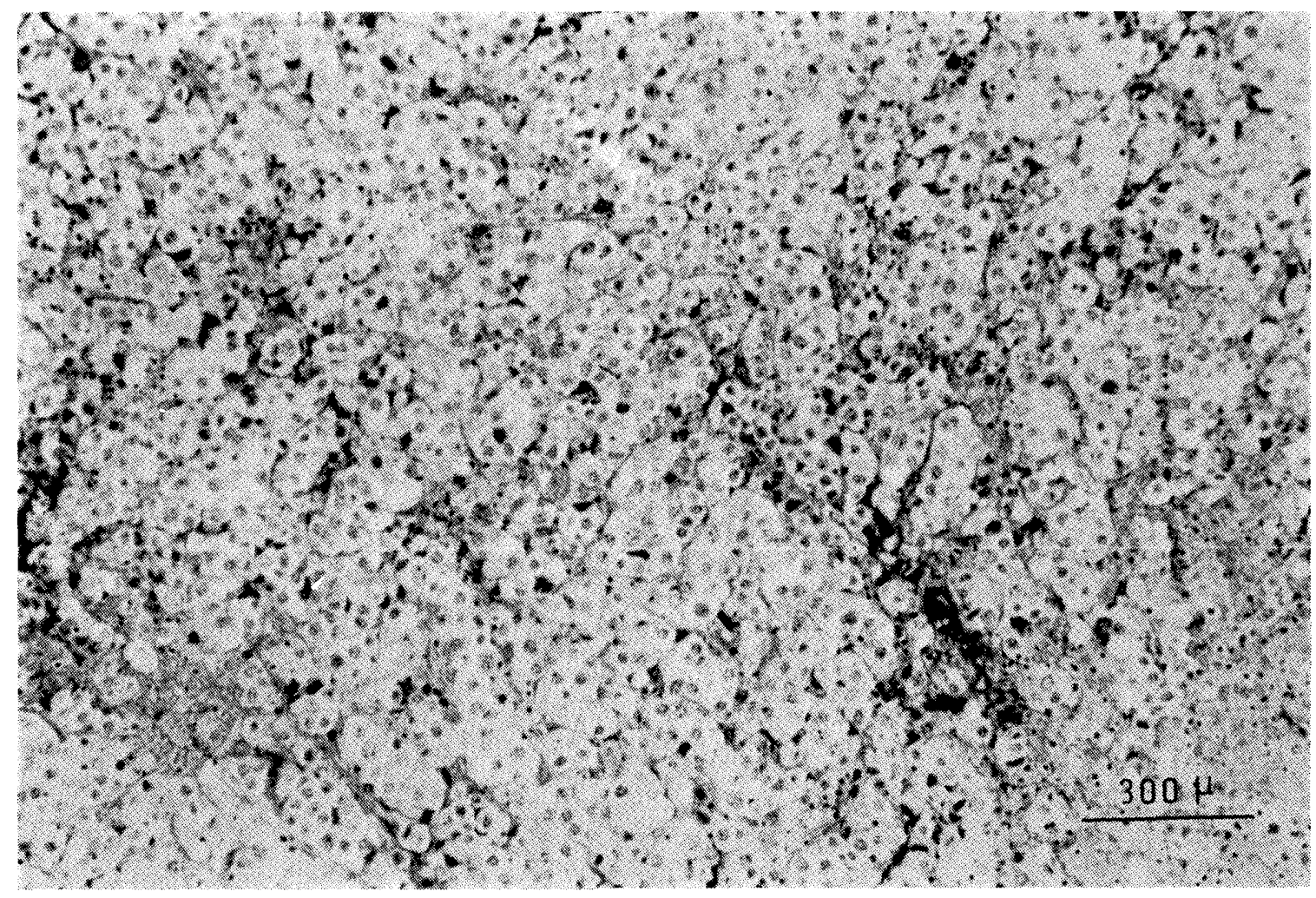

Fig. 2. Histologic findings of the tumor, showing groups of large clear neoplastic cells separated by delicate stroma and in some portions clusters of epitheloid cells. $\mathrm{HE} \times 58$ 


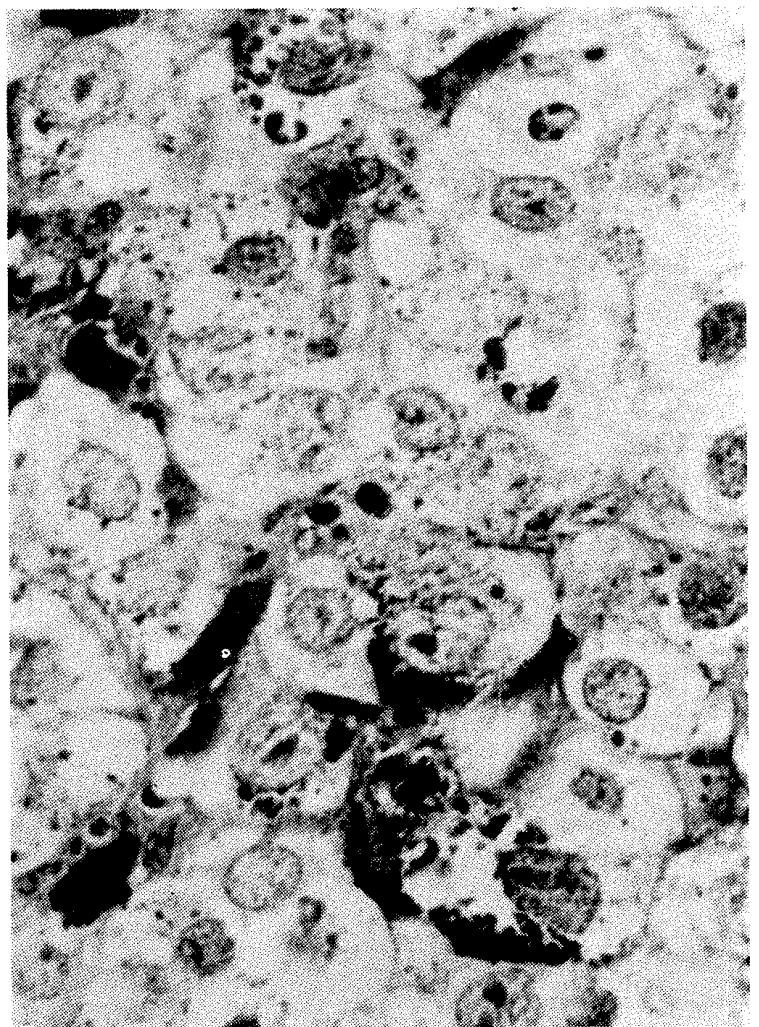

Fig. 3. PAS staining, roughly granular positive in clear cytoplasm of tumor cells. $\times 580$

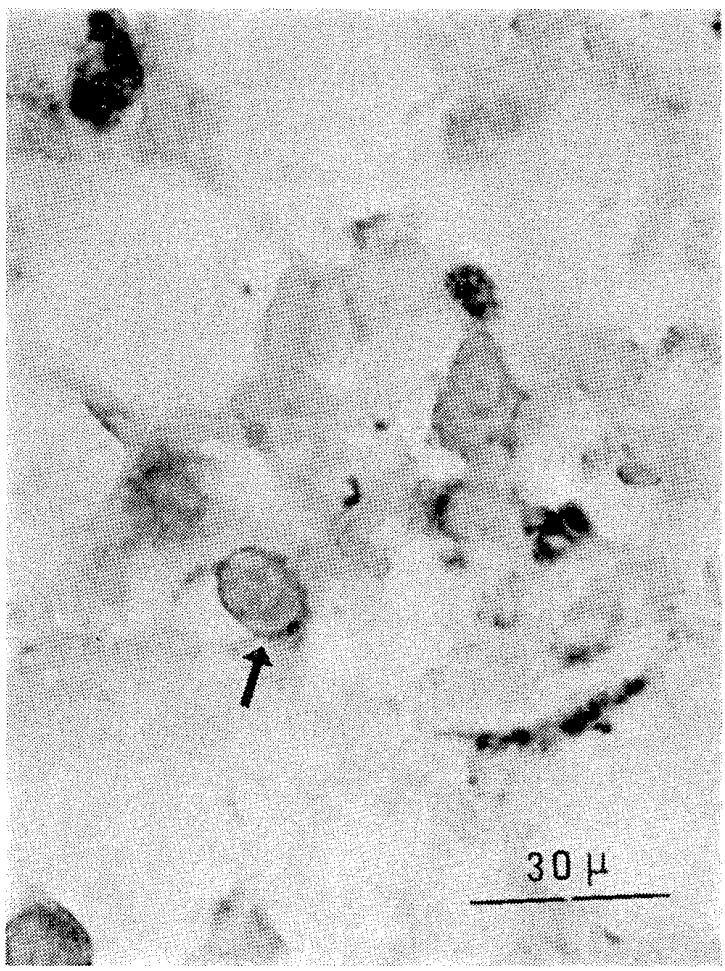

Fig. 5. AcPase staining, finely granular positive in some of the tumor cells (arrow). $\times 580$

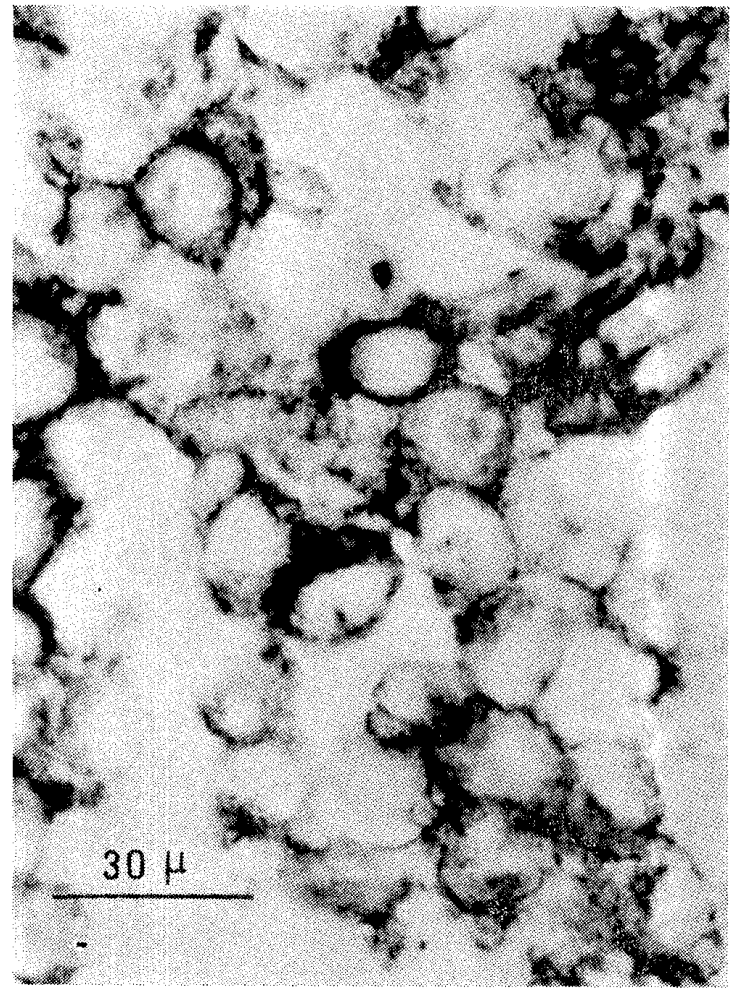

Fig. 4. AlPase staining, strongly positive on tumor cells. $\times 580$

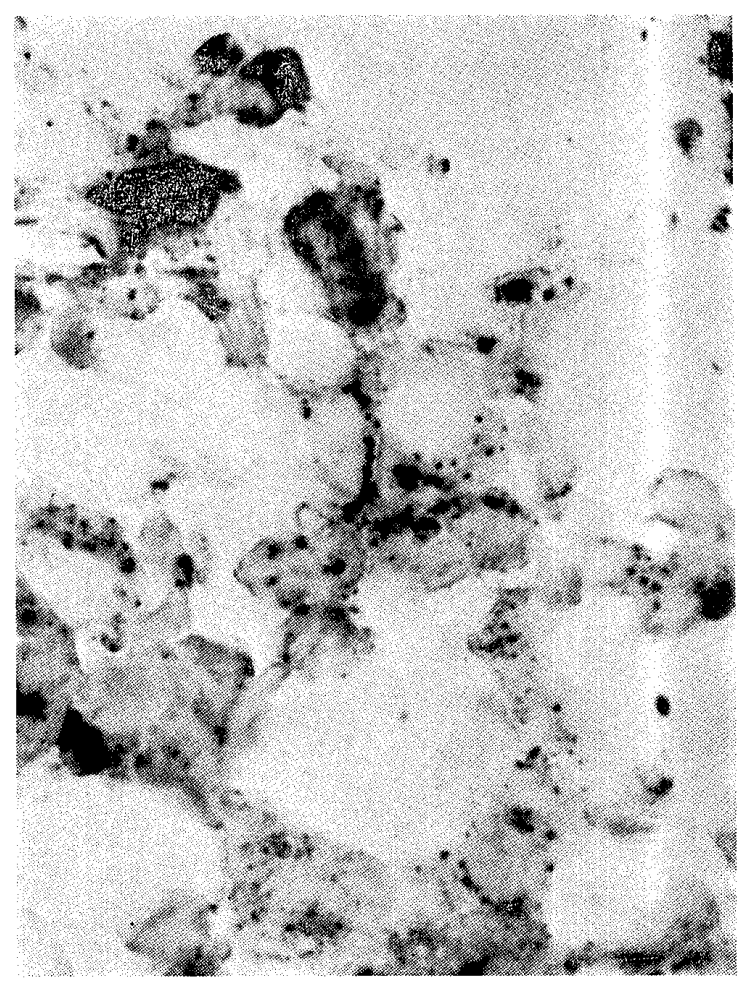

Fig. 6. $\alpha$-N. acet. est. staining, spotted positive in tumor cells. $\times 580$

Strong positive reactions of macrophages in the stroma are seen in the upper left corner of both Figs. 5 and 6 . 
Table 2. Enzyme histochemical findings

\begin{tabular}{|c|c|c|c|c|c|c|c|}
\hline Enzyme & & AlPase & AcPase & $\beta$-Gase & ATPase & $\begin{array}{l}\alpha-N \text {. acet. } \\
\text { esr. }\end{array}$ & $\begin{array}{l}\alpha \text {-N. but. } \\
\text { est. }\end{array}$ \\
\hline Activity & & Ht & + & + & - & H & - \\
\hline Inhibitor & $\mathrm{L}-\mathrm{Ph}$ & D-Ph L-H L-L $47^{\circ} \mathrm{C}$ & $65^{\circ} \mathrm{C}$ & & & & \\
\hline Inactivation & $\hat{i}$ & $>\vee>>>$ & $\downarrow \downarrow \downarrow$ & & & & \\
\hline
\end{tabular}

$c-\mathrm{N}$. but. est. activity was not demonstrated in the tumor cells. Strong diffuse activity of these esterases was found in stromal macrophages. Those findings are summarized in Table 2.

\section{Ultrastructural findings}

The tumor cells were generally $20-25 \mu \mathrm{m}$ in size, ovoid in shape (Fig. 7) and less frequently had a cytoplasmic process due to elongation of a portion of the cytoplasm (Fig. 8). They possessed large ovoid nuclei containing scanty heterochromatin and large nucleoli with distinct nucleolonema. The cytoplasm had a moderate number of mitochondria and a large number of glycogen granules dispersely or as aggregates (Fig. 9), and also some Golgi apparatus were well developed. Mitochondria were round or oval and their cristae showed an irregular arrangement. In spite of scanty endoplasmic reticulum on the whole, annulate lamellae as well as stacks of rough-surfaced endoplasmic reticulum were occasionally present (Fig. 10). No junctional complex was seen.

\section{Discussion}

Primary extragonadal germinoma has been documented as arising in the mediastinum, crania! cavity including pineal region and suprasellar region, and retroperitoneum. Of these extragonada! locations, the mediastinum has been by far the most common in the English literatures (Polansky et al., 1979.) In Japan, the mediastinal germ cell tumor has been rather less common (Endo et al., 1979) than the intracranial germ cell tumor which has a relatively high incidence (Koide et al., 1980). The incidence of female patients was lower than 10\% (Cox, 1975; Polansky et al., 1979) except for a report with 8 females in a group of 30 patients (Martini et al., 1974). The predominancy of males is more prominent in the mediastinal germ cell tumors than in the intracranial ones. The peak of age distribution was 15-35 years (Cox, 1975; Polansky et al., 1979).

Most of mediastinal germ cell tumors were histologically classified into germinoma and embryona! carcinoma. Embryonal carcinoma was more frequent in a certain paper (Martini et al., 1974) and germinoma was more frequent in another (Endo et al., 1979). Here in Japan the reports have mostly referred to germinoma. An exploratory excision was done on the present patient because of the tumor invasion into a portion of the right lung. The excised specimen revealed a histology of germinoma, though the admixture 


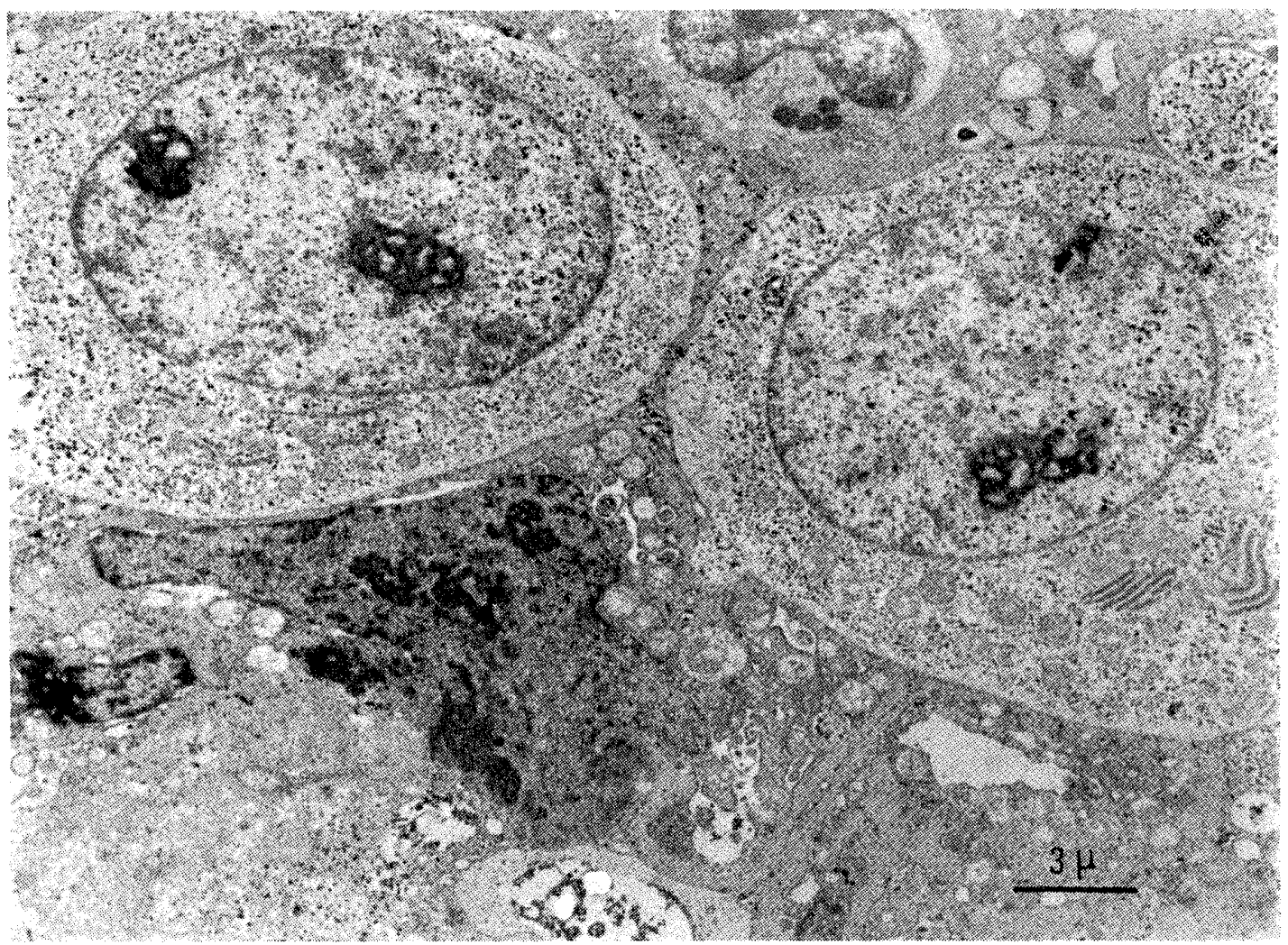

Fig. 7. Low magnification of tumor cells showing two ovoid cells and one irregular-shaped degenerated cell. $\times 4,000$

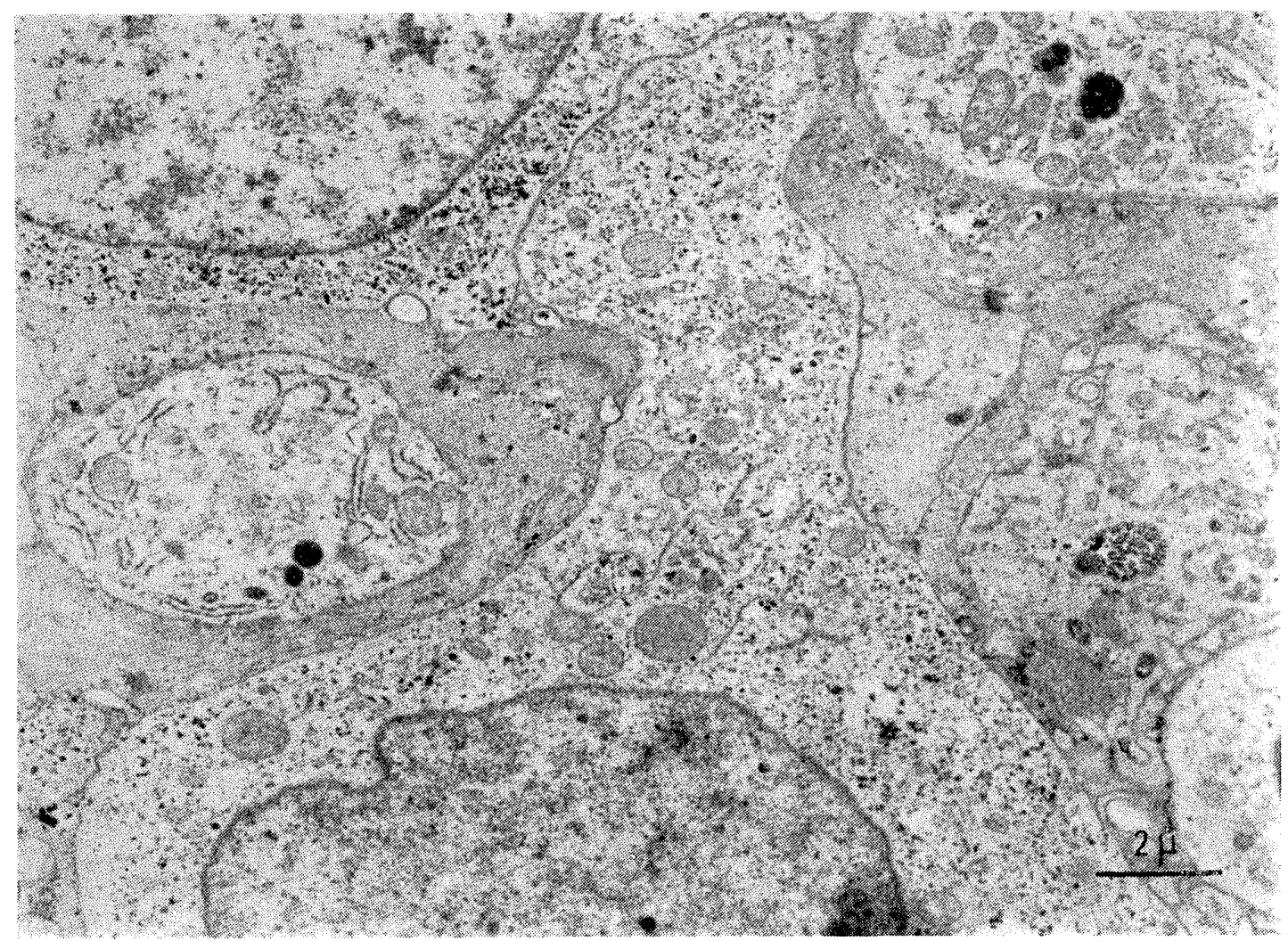

Fig. 8. A blunt cytoplasmic process. $\times 6,000$ 


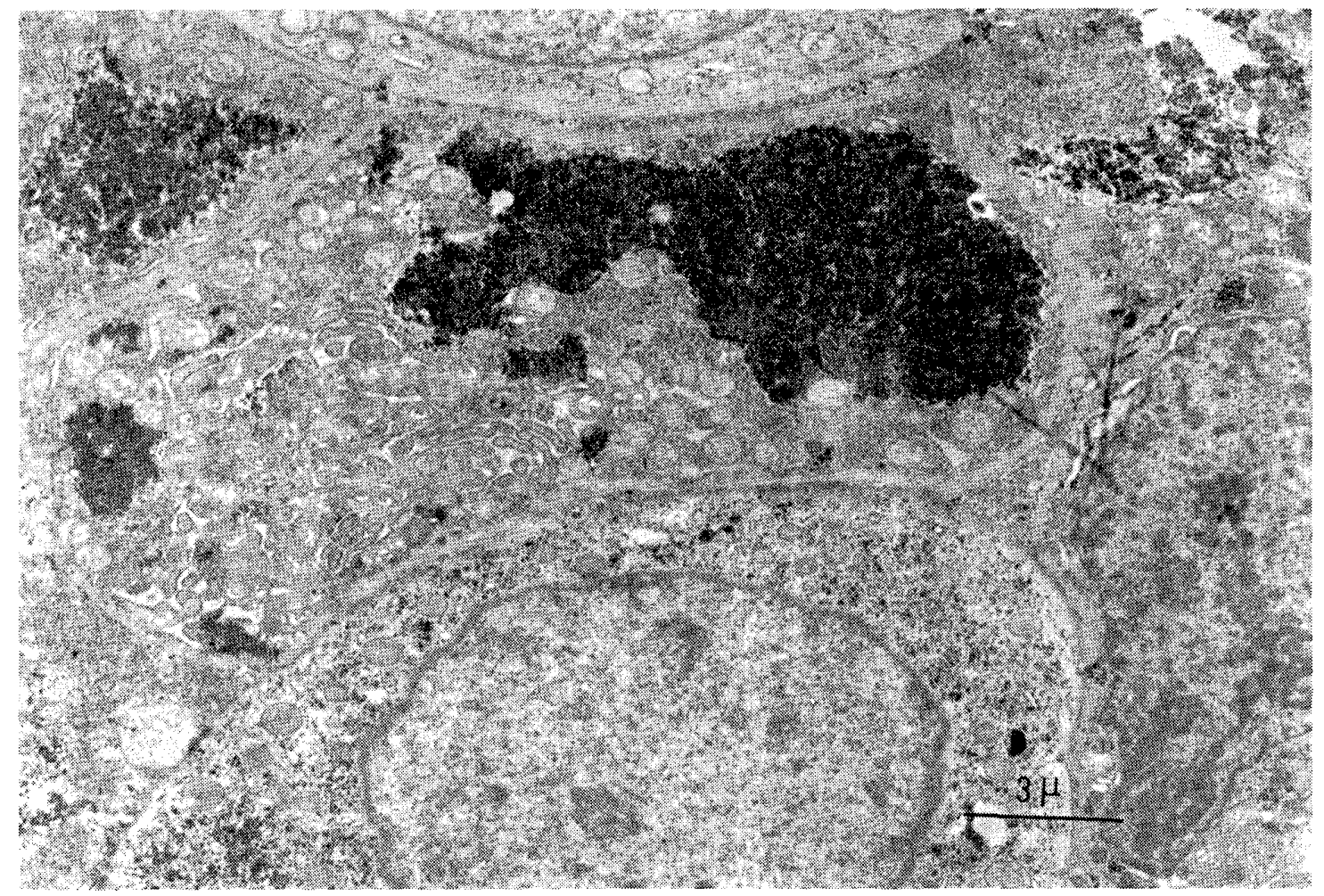

Fig. 9. Aggregates of glycogen granules, glycogen area. $\times 5,300$

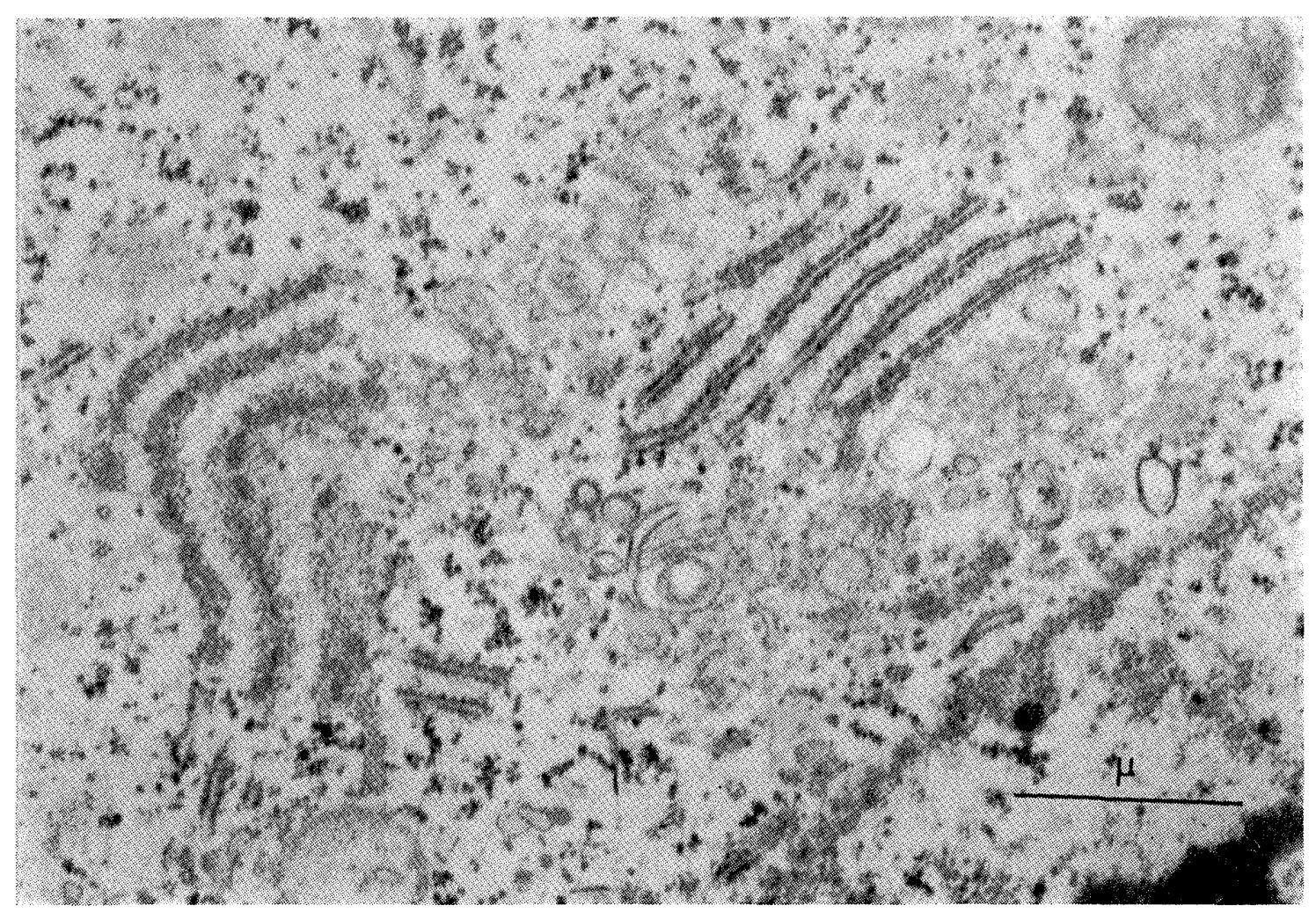

Fig. 10. Annulate lamellae and stack of r-ER. $\times 23,000$ 
of other components of germ cell tumor could not be excluded without a histological examination throughout the whole tumor.

To our knowledge, the enzyme histochemical study on mediastinal germinoma has never been described in any literature. The tumor cells of the present patient as well as intracranial germinoma cells (Beeley et al., 1973; Koide et al., 1980), ovarian dysgerminoma cells (Ueda et al., 1972) and seminoma cells (Beeley et al., 1973) characteristically showed a strong positive reaction to AlPase staining. Referring to a strong positive reaction to AlPase staining in human primordial germ cells (McKay et al., 1953), mouse embryos (Mulnard \& Huygens, 1978) and teratocarcinoma cells (Damjanov et al., 1971), these findings were stressed to be a basis of the hypothesis of germinomas originating from immature germ cells (Koide et al., 1980).

Regarding AlPase isoenzymes, Bernstine et al. (1973) noted AlPase appearing in mouse embryonal carcinoma cells resembled a renal or placental type of AlPase, Wahren et al. (1979) pointed out that seminoma tissues had placental AlPase contents which were higher than in non-seminomatous tumors as measured by radioimmunoassey and could be localized in tumor cells by immunofluorescence, and Benham et al. (1978) detected D-variant of placental AlPase in extracts of ovarian tumors. Sasaki \& Fishman (1973) asserted a locational deviation of the enzyme, in other words, a change of enzymorphological phenotypes in cancer cells, as they observed that mitochondrial AlPase was related to Regan AlPase while the cell membrane activity was non-Regan isoenzyme.

In the enzyme histochemical study of the present case, AlPase activity in tumor cells was completely inhibited by heating at $65^{\circ} \mathrm{C}$, and exhibited the same degree of sensitivity to several kinds of amino acids as that of proximal tubules of the kidney. According to these findings, AlPase was suspected to belong to the kidney type. Recently it was noticed that placental AlPase appeared to be a new marker for seminoma (Wahren et al., 1979). Further studies are expected on A.lPase isoenzyme of germinomas.

The electron microscopic study on germinoma has been carried out by many researchers (Cravioto \& Dart, 1973; Bjersing \& Cajander, 1977; Janssen \& Johnston, 1978; Akhtar \& Sidiki, 1979; Koide et al., 1980), since Pierce (1966) studied ultrastructurally on 13 testicular seminomas. The characteristic ultrastructures of germinoma cells were noted as follows: the individual tumor cells contained round to oval nuclei with evenly dispersed chromatin and prominent nucleoli manifesting a meshwork at times, and the cytoplasm was relatively simple without abundant organelles and contained moderate amounts of glycogen. Annulate lamellae were frequently observed. Pierce (1966) noted no junctional complex was found, but thereafter occasional desmosomes were encountered.

The ultrastructural observation on mediastinal germinoma was performed in only two cases (Levine, 1973; Polansky et al., 1979). For differentiating the germinoma from the thymoma, the most useful ultrastructural features of germinoma are a paucity of desmosomes, an absence of tonofilament, complex bizarre nucleoli, and short cytoplasmic processes. The features of the present tumor cells were almost identical to the germinoma cells in other sites except for the absence of desmosome. The absence of desmosome 
was considered to be rather useful for the differentiation of this tumor from the thymoma.

\section{References}

Akhtar, M. \& Sidiki, Y. (1979): Undifferentiated intratubular germ cell tumor of the testis: Light and electron microscopic study of a unique case. Cancer, 43: 2332-ż339.

Barka, T. \& Anderson, P. J. (1962): Histochemical methods for acid phosphatase using hexazonium pararosanilin as coupler. J. Histochem. Cytochem., 10: 741-753.

Beeley, J. M., Daly, J. J., Timperley, W. R. et al. (1973): Ectopic pinealoma: an unusual clinical presentation and a histochemical comparison with a seminoma of the testis. J. Neurol. Neurosurg. Psychiatry, 36: 864-873.

Benham, F. J., Povey, M. S. \& Harris, H. (1978): Placental-like alkaline phosphatase in malignant and benign ovarian tumors. Clin. Chim. Acta, 86: 201-215.

Bernstine, E. G., Hooper, M. L., Grandchamp, S. et al. (1973): Alkaline phosphatase activity in mouse teratoma. Proc. Nat. Acad. Sci., 70: 3899-3903.

Bjersing, L. \& Cajander, S. (1977): Ultrastructure of gonadoblastoma and disgerminoma (seminoma) in a patient with XY gonadal-dysgenesis. Cancer, 40: 1127-1137.

Cox, J. D. (1975): Primary malignant germinal tumors of mediastinum: study of 24 cases. Cancer, 36: $1162-1168$.

Cravioto, H. \& Dart, D. (1973): The ultrastructure of "pinealoma." J. Neuropathol. Exp. Neurol., 32: $552-564$.

Damjanov, I., Solter, D. \& Skreb, N. (1971): Enzyme histochemistry of experimental embryo-derived teratocarcinoma. Z. Krebsforsch., 76: 249-256.

Endo, H., Oohata, M., Iida, M. et al. (1979): Classification and therapy of primary mediastinal germ cell tumors. Nihon Kyobu Rinsho, 38: 245-259. (in Japanese)

Hayashi, M., Nakajima, Y. \& Fishman, M. H. (1964): The cytologic demonstration of $\beta$-glucuronidase employing naphthol AS-BI glucuronide and hexozanium pararosanilin: A preliminary report. J. Histochem. Cytochem., 12: 293-297.

Janssen, M. \& Johnston, W. H. (1978): Anaplastic seminoma of testis: Ultrastructural analysis of 3 cases. Cancer, 41: 538-544.

Koide, O., Watanabe, Y. \& Sato, K. (1980): A pathological survey of intracranial germinoma and pinealoma in Japan. Cancer, 45: 2119-2130.

Levine, G. D. (1973): Primary thymic seminoma: A neoplasm ultrastructurally similar to testicular seminoma and distinct from epithelial thymoma. Cancer, 31: 729-740.

Li, C. Y., Yam, L. T. \& Crosby, W. H. (1972): Histochemical characterization of cellular and structural elements of the human spleen. J. Histochem. Cytochem., 20: 1049-1058.

Martini, N., Golbey, R. B., Hajdu, S. I. et al. (1974): Primary mediastinal germ cell tumors. Cancer, 33: 763-769.

McDowell, E. M. \& Trump, B. F. (1976): Histologic fixatives suitable for diagnostic light and electron microscopy. Arch. Pathol. Lab. Med., 100: 105-414.

McKay, D. G., Hertig, A. T., Adams, E. C. et al. (1953): Histochemical observation on the germ cells of human embryos. Anat. Rec., 117: 201-219.

Mulnard, J. \& Huygens, R. (1978): Ultrastructural localization of nonspecific alkaline phosphatase during cleavage and blast cyst formation in the mouse. J. Embryol. Exp. Morphol., 44: 121131.

Pierce, G. B. (1966): Ultrastructure of human testicular tumors. Cancer, 19: 1963-1983.

Polansky, S. M., Barwick, K. W. \& Ravin, C. E. (1979): Primary mediastinal seminoma. Am. J. Roentgenol., 132: 17-21.

Posen, S. N., Neale, F. C. \& Clubb, J. S. (1965): Heat inactivation in the study of human alkaline 
phosphatase. Ann. Int. Med., 62: 1234-1243.

Rufo, M. B. \& Fishman, W. H. (1972): L-Homoarginine, a specific inhibitor of liver-type alkaline phsophatase, applied to the recognition of liver-type enzyme activity in rat intestine. J. Histochem. Cytochem., 20: 336-343.

Sasaki, M. \& Fishman, W. H. (1973): Ultrastructural studies on Regan and non-Regan isoenzymes of alkaline phosphatase in human ovarian cancer cells. Cancer Res., 33: 3008-3018.

Schantz, A., Sewall, W. \& Castleman, B. (1972): Mediastinal germinoma: A study of 21 cases with an excellent prognosis. Cancer, 30: 1189-1194.

Ueda, G., Hamanaka, N., Hayakawa, K. et al. (1972): Clinical, histochemical, and biochemical studies of an ovarian dysgerminoma with trophoblasts and Leydig cells. Am. J. Obst. Gynecol., 114: $748-754$.

Wachstein, M. \& Meisel, E. (1957): Histochemistry of hepatic phosphatases at a physiologic pH with special reference to the demonstration of bile canaliculi. Am. J. Clin. Pathol., 27: 13-23.

Wahren, B., Holmgren, P. A. \& Sigbrand, T. (1979): Placental alkaline phosphatase, alphafetoprotein and carcinoembryonic antigen in testicular tumors: Tissue typing by means of cytologic smears. Int. J. Cancer, 24: 749-753.

Watanabe, K. \& Fishman, W. H. (1964): Application of the sterospecific inhibitor L-phenylalanine to the enzymorphology of intestinal alkalline phosphatase. J. Histochem. Cytochem., 12: 252260.

Yam, L. T., Li, C. Y. \& Crosby, W. H. (1971): Cytochemical identification of monocytes and granulocytes. Am. J. Clin. Pathol., 55: 284-290.

Yoshimatsu, H., Ishikura, Y., Murakami, M. et al. (1980): A clinical study of patients with invasive mediastinal tumor. Kyobu Geka, 33: 446-455. (in Japanese)

縦隔ゼミノーム様腫演の一例：愫素組織化学的立作びに超微形態学的検詩

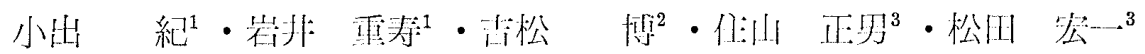

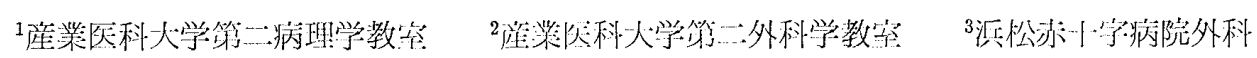

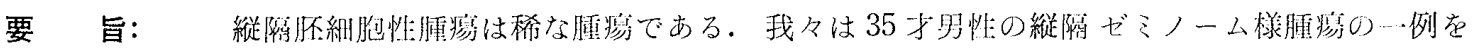

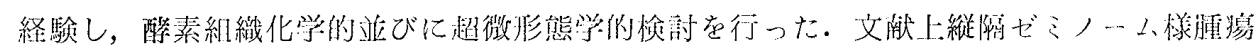

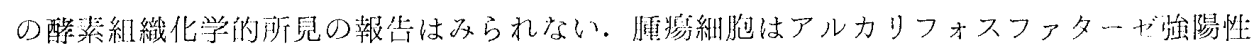

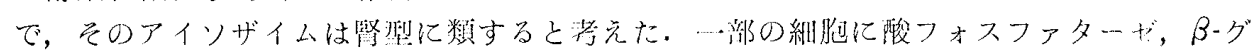

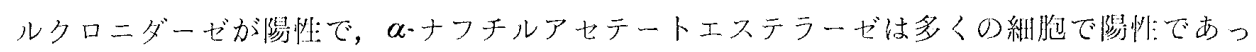
たが，アデノシントリフォスファターゼ， $\alpha$-ナフチルブチレートエステラ一ゼは陰性で

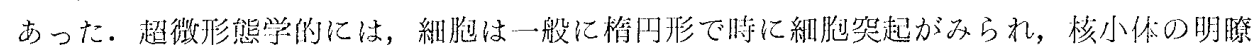
な類円形核を有し，細胞小器官は芑しいが多量のグリコーゲンを有し，一部細狍には有空 留板㧍よび重属性粗面小胞体がみられる。接着装置はみられなかった。他部に原発する肧

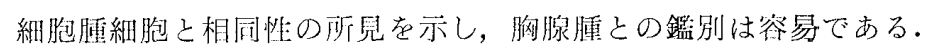

